\title{
Peningkatan Pengetahuan dan Sikap Ibu Tentang PHBS Tatanan Rumah Tangga (ASI Eksklusif) Di Kabupaten Sambas melalui Media Leaflet Berbahasa Daerah
}

\author{
Ria Damayanti*), Zahroh Shaluhiyah**), Kusyogo Cahyo***) \\ *) Alumni Magister Promosi Kesehatan Undip \\ Korespondensi: ummizaid17@ymail.com \\ **) Magister Promosi Kesehatan Universitas Diponegoro Semarang \\ ***) Bagian Pendidikan Kesehatan dan Ilmu Perilaku Fakultas Kesehatan Masyarakat \\ Universitas Diponegoro Semarang
}

\begin{abstract}
ABSTRAK
Peran media promosi kesehatan sangat penting dalam perubahan perilaku yang positif terhadap kesehatan. Media promosi kesehatan yang baik adalah yang melihat tingkat kebutuhan masyarakat, sedangkan media promosi kesehatan yang ada di Kabupaten Sambas masih bersifat sentralistik dan belum berbasis pada kebutuhan masyarakat setempat. Leaflet berbahasa daerah diharapkan dapat meningkatkan pengetahuan dan sikap ibu tentang Perilaku Hidup Bersih dan Sehat (PHBS) tatanan Rumah Tangga khususnya pada indikator ASI Eksklusif. Tujuan penelitian ini adalah untuk menganalisis pengaruh media leaflet berbahasa daerah terhadap peningkatan pengetahuan dan sikap tentang PHBS tatanan rumah tangga (ASI eksklusif) di Kabupaten Sambas. Penelitian ini menggunakan metode kuantitatif dengan pendekatan quasy experimental rancangan non equivalent control group, juga dilengkapi metode kualitatif berupa need assessment dan uji coba (pretesting) untuk pengembangan media leaflet. Penentuan sampel menggunakan tekhnik purposive sampling sebanyak 60 ibu rumah tangga yang terdiri dari masing-masing 20 ibu rumah tangga pada tiga kecamatan di Kabupaten Sambas. Hasil peneltian menunjukkan bahwa ada perbedaan pengetahuan ( $p$ value $<0,001)$ dan sikap ( $p$ value < 0,001) yang signifikan antara sebelum dan setelah perlakuan, dimana peningkatan pengetahuan dan sikap pada kelompok perlakuan dengan menggunakan media leaflet berbahasa daerah lebih tinggi dibanding dengan kelompok perlakuan dengan media leaflet berbahasa Indonesia dan kelompok tanpa perlakuan (kontrol).
\end{abstract}

Kata kunci: Leaflet, PHBS Rumah Tangga, ASI eksklusif

\section{ABSTRACT}

Increased Knowledge and Mother's Attitude About PHBS Household (Exclusive Breastfeeding) in District of Sambas With Leaflet local language; A good promotion media is one that considers each community's need. Leaflet using local language is expected to increase the knowledge and attitude of mothers about household clean and healthy lifestyle behaviors, especially exclusive breastfeeding indicators. The purpose of this study was to analyze the influence of local-language leaflets media to increase knowledge and attitudes about living a clean and healthy behaviors in order household (exclusive breastfeeding) in Sambas district. This study uses a quantitative method, Using quasi-experimental with a non-equivalent control group design and qualitative method with needs assessment and testing (pretesting). Samples are chosen using a purposive sampling technique, which consisted of 60 housewives which are divided into 20 housewives for each three districts in Sambas. The Result show that there are higher increased knowledge and attitudes in the group treated with the use of local language leaflet. Keywords : Leaflet, household clean and healthy lifestyle behavior, exclusive breastfeeding 


\section{PENDAHULUAN}

Saat ini, promosi kesehatan belum banyak merubah perilaku masyarakat menjadi Perilaku Hidup Bersih dan Sehat (PHBS). Oleh karena itu PHBS menjadi salah satu landasan dan program pembangunan kesehatan di Indonesia. Salah satu sasaran penerapan program PHBS adalah pada tatanan rumah tangga, yang bertujuan untuk meningkatkan derajat kesehatan keluarga dan produktivitas kerja setiap anggota keluarga (Kemenkes RI, 2010).

Proporsi nasional rumah tangga dengan PHBS baik adalah 32,3\%. Angka ini masih jauh dibawah target yang telah ditetapkan dalam Rencana Strategis Kementrian Kesehatan Tahun 2010-2014 yaitu 70\% rumah tangga sudah mempraktekkan PHBS tahun 2014 (Kemenkes RI, 2013). Dari hasil rekapitulasi data profil kesehatan kabupaten/kota tahun 2010, menunjukan bahwa di Kalimantan Barat dari 268.916 rumah tangga yang dipantau, sebesar 78.998 (29,4\%) merupakan Rumah Tangga ber Perilaku Hidup Bersih dan Sehat (Dinkes Prov. Kalbar, 2011). Dari survey pendahuluan di Dinas Kesehatan Kabupaten Sambas, diketahu bahwa dari 4.150 rumah tangga yang dipantau, hanya $896(21,59)$ rumah tangga yang ber-PHBS. Angka tersebut masih di bawah target Standar Pelayanan Minimal
(SPM) yaitu 50\% target nasional dan 40\% target kabupaten. (Dinkes Kab. Sambas, 2014). Pemberian Air susu Ibu (ASI) Eksklusif merupakan salah satu indikator PHBS tatanan rumah tangga. Tingginya AKB dan masalah gizi pada bayi dapat ditangani sejak awal dengan cara pemberian ASI. Menurut data SDKI tahun 2012, praktek pemberian ASI Eksklusif pada bayi sampai usia 4-5 bulan hanya 27\%, dan sampai usia 6 bulan sebesar $3,4 \%$. Hanya $15,3 \%$ bayi yang mendapatkan ASI eksklusif di Kabupaten Sambas. Dari data tersebut menunjukkan bahwa kesadaran masyarakat Indonesia khususnya masyarakat sambas dalam pemberian ASI Eksklusif masih sangat memprihatinkan. Hambatan keberhasilan pemberian ASI eksklusif di Kabupaten Sambas salah satunya adalah kuatnya kepercayaan masyarakat akan mitos di lingkungannya. Contohnya adalah bayi baru lahir yang menangis dianggap lapar dan ASI saja dianggap tidak cukup membuat bayi kenyang, maka kemudian bayi diberi makanan tambahan seperti pisang dan bubur saring. Untuk dapat berperilaku hidup bersih dan sehat khususnya pada pemberian ASI eksklusif maka dibutuhkan informasi. Informasi kesehatan dapat disampaikan melalui promosi kesehatan dan promosi kesehatan tidak lepas dari media karena melalui media, pesan-pesan yang 
disampaikan dapat lebih menarik dan mudah dipahami.

Mengingat keragaman kultur budaya di Indonesia, tentunya akan ada sejumlah faktorfaktor penghambat dimana bahasa, simbol dan lambang-lambang yang terkomunikasikan mengalami proses panjang sebelum memberikan pengaruh balik terhadap bahasa, simbol dan lambang-lambang yang dimaksudkan (Cahyadi,2012).

Sehingga menurut peneliti perlu di rancang media yang sesuai dengan kebutuhan dan nilainilai sosial budaya masyarakat sehingga pesan dapat lebih efektif untuk merubah pengetahuan dan sikap masyarakat tentang PHBS tatanan Rumah Tangga khususnya tentang ASI Eksklusif.

\section{METODE PENELITIAN}

Jenis penelitian yang digunakan adalah quasy experimental (eksperimen semu, disebut demikian karena eksperimen ini belum memenuhi persyaratan seperti cara eksperimen sesungguhnya. Dimana syarat-syarat pokok yang tidak dapat dipenuhi oleh penelitian jenis ini adalah tidak adanya randomisasi dan kontrol terhadap variabel-variabel yang berpengaruh terhadap eksperimen tidak dilakukan (Notoatmodjo, 2012 dan Sugiyono, 2013).

Analisis kuantitatif digunakan untuk melihat pengaruh media leaflet berbahasa daerah terhadap peningkatan pengetahuan dan sikap ibu tentang perilaku hidup bersih dan sehat (PHBS) tatanan rumah tangga khususnya pada indikator ASI eksklusif. Selain pendekatan kuantitatif, penelitian ini juga didukung dengan metode kualitatif untuk menganalisis kebutuhan sasaran terhadap media promosi kesehatan dan untuk mengembangkan media melalui tekhnik focus group discussion (FGD). Penentuan sampel dilakukan dengan purposive sampling. Pengambilan sampel secara purposive didasarkan pada suatu pertimbangan tertentu yang dibuat oleh peneliti sendiri berdasarkan ciri atau sifat-sifat populasi yang sudah diketahui sebelumnya (Notoatmodjo, 2012). kriteria sampel yaitu ibu rumah tangga yang berusia antara 26-35 tahun, memiliki pendidikan minimal tingkat SMP dan maksimal tingkat SMA, merupakan warga asli di Kabupaten Sambas. Untuk penelitian eksperimen sederhana yang menggunakan kelompok eksperimen dan kelompok kontrol, maka jumlah sampel masing-masing kelompok antara 10 sampai dengan 20 (Sugiyono, 2007). Dengan pertimbangan peneliti, sampel dalam penelitian ini yaitu 20 responden dari Kecamatan Paloh sebagai kelompok intervensi leaflet berbahasa daerah (intervensi BD), 20 responden dari Kecamatan Tangaran sebagai kelompok intervensi leaflet berbahasa Indonesia (intervensi $\mathrm{BI}$ ), dan 20 responden 
dari Kecamatan Galing sebagai kelompok kontrol tanpa pemberian leaflet. 6 orang ibu rumah tangga dari Kecamatan Teluk Keramat sebagai peserta Focus Group Discussion (FGD) pada tahap need assessment. Dan 8 orang ibu rumah tangga sebagai peserta FGD pada tahap uji coba/pretesting media.

Analisis yang digunakan dalam penelitian ini menggunakan metode kuantitatif. Analisis univariat Dilakukan untuk memperoleh gambaran karakteristik responden meliputi umur, jenis kelamin, pendidikan, dan pekerjaan, disajikan secara deskriptif dalam bentuk tabel distribusi frekuensi. Analisis deskriptif dimaksudkan untuk mengetahui sebaran dari frekuensi jawaban responden terhadap kuesioner yang telah diisi dan kecenderungannya. Analisa bivariat dilakukan untuk menganalisa perbedaan pengetahuan, dan sikap responden tentang PHBS tatanan rumah tangga (ASI eksklusif) sebelum dan sesudah perlakuan. Analisa data pada penelitian ini menggunakan uji Paired $t$ Test atau uji $\mathrm{t}$ berpasangan untuk data berdistribusi normal, dan uji Wilcoxon Untuk data tidak berdistribusi normal. Analisis multivariat digunakan untuk menguji apakah rerata dua kelompok atau lebih berbeda secara signifikan ataukah tidak. Uji One Way Anova dilakukan terhadap variabel yang berdistribusi normal $(\mathrm{p}>0,05)$, dan dilakukan uji Kruskal-Wallis terhadap variabel yang tidak berdistribusi normal $(\mathrm{p}<0,05)$ (Riwidikdo, 2012).

\section{HASIL DAN PEMBAHASAN}

\section{Pengembangan Media Leaflet PHBS Rumah} Tangga (ASI Eksklusif)

Berdasarkan hasil need assessment melalui Focus Group Discussion (FGD), media yang dipilih adalah leaflet karena leaflet dianggap sebagai media yang praktis yang bisa dibawa kemana saja, mudah disimpan misalnya di dalam dompet, dan bisa dibaca kapan saja mereka ingin membacanya kembali. Berdasarkan penelitian tentang media booklet dan leaflet yang dikaji oleh Adawiyah (2003), Bangun (2001), Yanti (2002), dan Nuh (2004) telah membuktikan bahwa media komunikasi berbentuk media cetak tersebut sangat efektif dalam meningkatkan pengetahuan dan mengubah sikap khalayak sasarannya (Marlina dkk, 2009). Peserta merasa perlu mengetahui lebih banyak tentang ASI eksklusif sehingga mereka mempunyai alasan dan motivasi untuk dapat memberikan ASI eksklusif pada bayi mereka nantinya. Hal ini sesuai dengan yang dikatakan Kartajaya dalam bukunya yang berjudul "Winning the Mom Market in Indonesia" bahwa setiap ibu selalu ingin memberikan yang terbaik untuk anak-anak mereka (Kartajaya, 2005).

Materi yang dimuat dalam leaflet adalah pengertian PHBS rumah tangga, 10 indikator PHBS rumah tangga, pengertian ASI eksklusif, penjelasan tentang kolostrum, keunggulan ASI, 
manfaat pemberian ASI eksklusif, cara menyusui yang benar, cara menjaga mutu dan jumlah produksi ASI, cara bagi ibu bekerja untuk dapat memberikan ASI eksklusif, dimana berarti ibu juga perlu mengetahui tentang cara penyimpanan dan pemberian ASI yang disimpan di rumah.

Dalam tahap ini peneliti kemudian membuat desain awal media leaflet PHBS Rumah Tangga (ASI eksklusif). Leaflet selanjutnya diuji coba (pretesting) untuk menentukan unsur-unsur mana dari media leaflet yang perlu dirubah agar informasi atau pesan yang ada dalam leaflet dapat dengan mudah diterima oleh sasaran. Uji coba menjamin bahwa sasaran dapat memahami pesan yang disampaikan dan juga menjamin ketepatan kondisi sosial budayanya (Mantra, 1997).

Berdasarkan hasil pretesting media, maka diperoleh kesimpulan bahwa peserta telah mengerti dan cukup mudah memahami isi materi yang ada pada leaflet. Peserta menilai penggunaan bahasa daerah dalam penulisan materi leaflet sangat menarik. Masyarakat merasa menjadi bagian dari leaflet karena bahasa dalam leaflet adalah bahasa yang mereka pergunakan sehari-hari. Hal ini sesuai dengan teori yang menyatakan bahwa ketika sasaran terlibat dalam suatu proses komunikasi, ada kecenderungan untuk menghubungkan aspek-aspek dari pesan tersebut kepada situasi personal dirinya. Sasaran tersebut mungkin akan membayangkan dan menempatkan dirinya dalam iklan, menjadi bagian dan merasakan empati serta emosi terhadap iklan yang dilihatnya (Shim \& Terrence, 2004).

\section{Karakteristik Responden}

Responden adalah ibu rumah tangga yang berusia antara 26 sampai 35 tahun, memiliki pendidikan minimal tingkat SMP dan maksimal tingkat SMA, dan merupakan warga asli (lahir dan menetap) di Kabupaten Sambas.

Usia; Persentase responden usia $<30$ tahun (26-29 tahun) pada kelompok intervensi BD sebesar $40 \%$. Persentase tersebut lebih kecil dari Persentase responden usia $<30$ tahun pada kelompok intervensi BI sebesar 50\%, dan kelompok kontrol sebesar 45\%. Pada kelompok intervensi BD dan kelompok kontrol, persentase responden usia $\geq 30$ tahun (30-35 tahun) lebih besar dibanding responden usia < 30 tahun, dimana kelompok intervensi BD memiliki persentas lebih besar yaitu $60 \%$ dan kelompok kontrol 55\%. Sedangkan pada kelompok intervensi $\mathrm{BI}$, responden usia $<30$ tahun dan usia $\geq 30$ tahun prosentasenya sama yaitu $50 \%$.

Erikson membagi usia menjadi delapan tahap perkembangan, masing-masing tahap perkembangan memiliki ciri khas atau karakteristik tersendiri yang membedakan 
tahap perkembangan tersebut dengan tahap perkembangan lainnya, demikian halnya dengan tugas perkembangan pada masingmasing tahap. Pada tahap usia dewasa muda (26 - 35 tahun), seseorang sedang giatnya mencari informasi atau pengetahuan tentang suatu hal. (Potter \& Perry, 2009)

Pendidikan; Pada ketiga kelompok, prosentase tingkat pendidikan responden relatif sama, dimana prosentase responden dengan pendidikan SMP/sederajat lebih kecil dibanding responden dengan pendidikan SMA/sederajat. Prosentase responden yang berpendidikan SMP pada kelompok intervensi BD dan kelompok kontrol sama yaitu $45 \%$, dan pada kelompok intervensi BI juga tidak berbeda jauh yaitu $40 \%$. Responden yang berpendidikan SMA pada kelompok intervensi BI prosentasenya lebih besar yaitu $60 \%$, dibanding dengan kelompok intervensi BD dan kontrol yang memiliki prosentase yang sama yaitu $55 \%$.

Pendidikan diasumsikan ada kaitannya dengan pengetahuan ibu dalam memberikan ASI eksklusif, hal ini sejalan dengan teori yang mengatakan bahwa seseorang yang berpendidikan lebih tinggi akan mempunyai pengetahuan yang lebih luas dibandingkan dengan tingkat pendidikan rendah (Notoatmodjo, 2007). Semakin tinggi tingkat pendidikan seseorang maka dia akan lebih mudah menerima dan menyelesaikan hal-hal baru (Tanjung \& Tristanti, 2011). Selaras dengan pendapat Rochalia (2005) bahwa pendidikan merupakan tingkat intelegensia yang berhubungan dengan daya pikir, semakin tinggi tingkat pendidikan seseorang semakin luas ilmu pengetahuan sehingga menimbulkan cara pikir yang lebih baik (Rochalia, 2005).

Status Pekerjaan; Responden yang bekerja sebagai petani memiliki persentase yang paling besar baik pada kelompok intervensi BD, kelompok intervensi BI, maupun pada kelompok kontrol. Persentase responden yang bekerja sebagai petani pada ketiga kelompok relatif sama, dimana kelompok intervensi BI persentasenya lebih besar yaitu 45\%, sedangkan pada kelompok intervensi BD dan kelompok kontrol persentasenya sama yaitu $40 \%$. Jenis pekerjaan yang persentasenya paling kecil adalah pegawai, pada kelompok intervensi BD yaitu 10\%, lebih besar sedikit dari kelompok intervensi BI yang hanya 5\%. Sedangkan pada kelompok kontrol, tidak terdapat responden yang bekerja sebagai pegawai. Pekerjaan responden selanjutnya dikelompokkan menjadi 2 yaitu bekerja dan tidak bekerja. Pekerjaan yang masuk dalam kelompok bekerja adalah pegawai, wiraswasta, petani, dan buruh. Dan yang masuk dalam kelompok tidak bekerja adalah ibu rumah tangga. baik pada kelompok intervensi BD, 
kelompok intervensi $\mathrm{BI}$, maupun kelompok kontrol, persentase responden yang bekerja lebih besar dibanding yang tidak bekerja. Persentase responden yang bekerja paling besar pada kelompok kontrol yaitu $80 \%$, tidak berbeda jauh dengan kelompok intervensi BD yaitu $75 \%$ dan kelompok intervensi BI $70 \%$. Sedangkan untuk responden yang tidak bekerja paling banyak pada kelompok intervensi BI yaitu 30\%, relatif sama dengan kelompok intervensi $\mathrm{BD}$ sebesar $25 \%$, dan kelompok kontrol $20 \%$.

Bekerja adalah kegiatan melakukan pekerjaan dengan maksud memperoleh penghasilan atau keuntungan paling sedikit 1 jam dalam seminggu. Bekerja selama 1 jam tersebut harus dilakukan berturut-turut, termasuk pekerjaan keluarga tanpa upah yang membantu dalam kegiatan usaha atau ekonomi (Afrose dkk, 2012).

Pada penelitian sebelumnya, responden yang bersikap baik paling banyak adalah responden yang berstatus tidak bekerja. Hal ini diasumsikan karena kesempatan yang dimiliki oleh ibu lebih banyak, sehingga ibu akan memiliki kesiapan dan kesediaan untuk memberikan ASI pada bayinya nanti (Lestari dkk, 2013). Bagi ibu yang bekerja, waktu dan kesempatan untuk merawat anak sangat terbatas, sehingga penyapihan akan dilakukan lebih cepat daripada ibu yang tidak bekerja (Afrose dkk, 2012)

Pengetahuan Responden Sebelum dan Setelah Perlakuan

Sebelum diberikan perlakuan, rerata skor pengetahuan paling tinggi terdapat pada kelompok kontrol yaitu 49,21 dengan nilai minimum 36,84 dan maksimum 68,42, tidak berbeda jauh dengan kelompok intervensi BD 47,90 dengan nilai minimum 31,58 dan maksimum 68,42 , dan yang paling rendah pada kelompok intervensi BI yaitu 47,37 dengan nilai minimum 31,58 dan maksimum 63,16. Hasil uji One Way Anova, perbedaan rerata skor pengetahuan antara kelompok intervensi BD dengan kelompok Intervensi BI $p=0,883$, antara kelompok BD dengan kelompok kontrol $\mathrm{p}=0,713$, dan antara kelompok intervensi $\mathrm{BI}$ dengan Kelompok kontrol $p=0,607$. Nilai $p>\alpha$ $(\alpha=0,05)$, dapat disimpulkan bahwa tidak ada perbedaan rerata skor pengetahuan antara ketiga kelompok saat sebelum perlakuan (pretest).

Setelah diberikan perlakuan, responden kelompok intervensi BD memili rerata skor pengetahuan paling tinggi yaitu 80,00 dengan nilai minimum 63,16 dan maksimum 94,74, angka tersebut jauh lebih tinggi dibanding dengan kelompok intervensi BI 69,21 dengan nilai minimum 52,63 dan maksimum 84,21, 
dan kelompok kontrol 51,32 dengan nilai minimum 36,84 dan maksimum 68,42. Hasil uji Kruskal-Wallis, perbedaan skor pengetahuan antara kelompok intervensi BD dengan kelompok Intervensi BI $\mathrm{p}=0,001$, antara kelompok BD dengan kelompok kontrol $\mathrm{p}<$ 0,001, dan antara kelompok intervensi BI dengan Kelompok kontrol $\mathrm{p}<0,001$. Nilai $\mathrm{p}<\alpha$ $(\alpha=0,05)$, dapat disimpulkan bahwa terdapat perbedaan skor pengetahuan yang signifikan antara ketiga kelompok setelah perlakuan.

Skor pengetahuan pada kelompok Intervensi BD mengalami peningkatan dengan rerata sebesar 32,11, kelompok intervensi BI mengalami peningkatan sebesar 21,84 dan pada kelompok kontrol sebesar 2,11. Hasil uji statistik Kruskal-Wallis, perbedaan peningkatan skor pengetahuan antara kelompok intervensi BD dengan kelompok Intervensi BI $\mathrm{p}<0,001$, antara kelompok BD dengan kelompok kontrol $\mathrm{p}<0,001$, dan antara kelompok intervensi BI dengan Kelompok kontrol $\mathrm{p}<0,001$. Nilai $\mathrm{p}<\alpha(\alpha=0,05)$, dapat disimpulkan bahwa ada perbedaan peningkatan skor pengetahuan yang signifikan antara ketiga kelompok, dan peningkatan paling besar terjadi pada kelompok intervensi BD. Hal ini berarti bahwa pemberian informasi tentang PHBS Rumah Tangga (ASI Eksklusif) melalui media leaflet berbahasa daerah lebih berpengaruh dalam meningkatkan pengetahuan responden tentang PHBS Rumah Tangga (ASI Eksklusif). Kurangnya kesadaran atau pengetahuan ibu tentang pentingnya ASI eksklusif akan berdampak pada rendahnya motivasi ibu dalam penerapan ASI eksklusif. Peningkatan pengetahuan dapat dilakukan dengan pemberian informasi melalui media leaflet. Ini sejalan dengan penelitian oleh Purniati Muslikha dan Sugi Purwanti yang hasilnya adalah bahwa leaflet ASI eksklusif berperan terhadap peningkatan pengetahuan dan motivasi ibu tentang ASI eksklusif dengan nilai $\mathrm{p}<0,001$ (Muslikha \& Purwanti, 2011).

Hal ini menunjukkan bahwa pendidikan kesehatan sangat berpengaruh terhadap pengetahuan, dimana telah terjadi perubahan pengetahuan seperti yang diharapkan yaitu dari tidak tahu menjadi tahu. Hasil ini juga didukung oleh penelitian Beker, Wilson, Nodstrom, dan Lagwand (2007) bahwa ada pengaruh yang bermakna dari pendidikan kesehatan dengan menggunakan leaflet terhadap peningkatan pengetahuan. Pengetahuan yang diperoleh dari pendidikan kesehatan berdampak positif dalam perubahan perilaku akibat proses belajar, karena belajar adalah proses perubahan dari tidak tahu menjadi tahu (Mandesa dkk, 2014). Asumsi di atas sejalan dengan pendapat Notoatmodjo (2007) yaitu pendidikan kesehatan sangat berperan dan berpengaruh 
terhadap pengetahuan seseorang, dimana kegiatan pendidikan yang dilakukan dengan cara menyebarluaskan pesan, menanamkan keyakinan sehingga masyarakat tidak hanya sadar, tahu, dan mengerti, tetapi juga mau dan bisa melaksanakan suatu anjuran yang ada kaitannya dengan kesehatan (Mandesa dkk, 2014).

Sikap Responden Sebelum dan Setelah Perlakuan

Sebelum diberikan perlakuan rerata skor sikap responden pada ketiga kelompok relatif sama, dan yang paling tinggi pada kelompok intervensi BD yaitu 66,06 dengan nilai minimum 56,57 dan maksimum 75,29, kemudian kelompok kontrol 64,71 dengan niali minimum 57,65 dan maksimum 72,94, dan yang paling rendah pada kelompok intervensi BI yaitu 64,24 dengan nilai minimum 51,76 dan maksimum 72,94. Hasil uji One Way Anova, perbedaan rerata skor sikap antara kelompok intervensi BD dengan kelompok Intervensi BI $\mathrm{p}=0,222$, antara kelompok BD dengan kelompok kontrol $\mathrm{p}=0,364$, dan antara kelompok intervensi BI dengan Kelompok kontrol $\mathrm{p}=0,751$. Nilai $\mathrm{p}>\alpha(\alpha=0,05)$, dapat disimpulkan bahwa tidak ada perbedaan ratarata skor sikap antara ketiga kelompok saat sebelum perlakuan (pre-test).
Setelah diberikan perlakuan, rerata skor sikap paling tinggi terdapat pada kelompok intervensi BD yaitu 77,59 dengan nilai minimum 65,88 dan maksimum 88,24. Sedangkan pada kelompok intervensi BI nilainya lebih rendah dibanding intervensi BD yaitu 72,12 dengan nilai minimum 63,53 dan maksimum 81,18. Rerata skor pengetahuan kelompok kontrol 64,88 dengan nilai minimum 58,82 dan maksimum 71,76.

Hasil uji Kruskal-Wallis, perbedaan skor sikap antara kelompok intervensi BD dengan kelompok Intervensi BI $\mathrm{p}=0,003$, antara kelompok BD dengan kelompok kontrol $\mathrm{p}<0,001$, dan antara kelompok intervensi BI dengan Kelompok kontrol $\mathrm{p}<0,001$. Nilai $\mathrm{p}<\alpha$ $(\alpha=0,05)$, dapat disimpulkan bahwa terdapat perbedaan skor pengetahuan yang signifikan antara ketiga kelompok setelah perlakuan.

Skor sikap pada kelompok Intervensi BD mengalami peningkatan dengan rerata sebesar 11,53, kelompok intervensi BD mengalami perubahan sebesar 7,88 dan pada kelompok kontrol sebesar 0,17. Hasil uji statistik KruskalWallis, perbedaan peningkatan skor sikap antara kelompok intervensi BD dengan kelompok Intervensi BI $\mathrm{p}<0,001$, antara kelompok BD dengan kelompok kontrol $\mathrm{p}<$ 0,001, dan antara kelompok intervensi BI dengan Kelompok kontrol $\mathrm{p}<0,001$. Nilai $\mathrm{p}<\alpha$ $(\alpha=0,05)$, dapat disimpulkan bahwa ada 
perbedaan peningkatan skor sikap yang sangat signifikan antara ketiga kelompok, dan peningkatan paling besar terjadi pada kelompok intervensi BD. Hal ini berarti bahwa pemberian informasi tentang PHBS Rumah Tangga (ASI Eksklusif) melalui media leaflet berbahasa daerah lebih berpengaruh dalam meningkatkan sikap positif responden tentang PHBS Rumah Tangga (ASI Eksklusif).

Hasil penelitian ini sejalan dengan penelitian Nasution N.A.H yang hasilnya adalah bahwa media promosi kesehatan (leaflet) efektif untuk meningkatkan skor pengetahuan dan skor sikap ibu hamil tentang IMD dan ASI eksklusif dengan nilai $\mathrm{p}<0,001$ (Nasution, 2010). Dan sejalan dengan penelitian Supardi, dkk yang memperoleh kesimpulan bahwa metode ceramah dan media leaflet berpengaruh terhadap peningkatan skor sikap tentang pengobatan sendiri dengan nilai $\mathrm{p}=0,004$ (Supardi dkk, 2002).

\section{SIMPULAN}

Karakteristik responden pada kelompok intervensi (kelompok intervensi leaflet berbahasa daerah dan kelompok intervensi leaflet berbahasa Indonesia) dan kontrol yang meliputi usia, pendidikan, dan pekerjaan secara statistik tidak ada perbedaan. Tidak ada perbedaan pengetahuan $(\mathrm{p}=868)$ dan sikap $(\mathrm{p}=0,446)$ antara ketiga kelompok sebelum perlakuan. Intervensi dengan leaflet berbahasa daerah lebih efektif dibandingkan dengan leaflet berbahasa Indonesia dalam meningkatkan pengetahuan dan sikap tentang PHBS tatanan rumah tangga (ASI eksklusif) di Kabupaten Sambas, yaitu sebesar 32,11 berbanding 21,84 untuk pengetahuan dan sebesar 11,53 berbanding 7,88 untuk sikap.

\section{DAFTAR PUSTAKA}

Afrose L, Banu B, Ahmad KR, Khanom K.

Factor Associated with Knowledge about Breastfeeding among Female Garment Workers in Dhaka City. WHO Sout-East Asia Journal of Public Health. 2012;1:249.

Badan Penelitian dan Pengembangan Kesehatan. Riset Kesehatan Dasar Tahun 2013. Kemenkes RI, Jakarta, 2013.

Bidang Kesehatan Keluarga dan Promosi Kesehatan. Profil PHBS Dinas Kesehatan Kabupaten Sambas Tahun 2013. Dinas Kesehatan Kabupaten Sambas, Sambas, 2014.

Cahyadi D. Konten Lokal Dalam Desain Media Promosi Kesehatan. Kompasiana, Jakarta,2012.

https://www.kompasiana.com/(diakses 10 Maret 2014).

Dinas Kesehatan Provinsi Kalimantan Barat. Profil Kesehatan Provinsi Kalimantan 
Barat Tahun 2010. Dinas Kesehatan

Provinsi Kalimantan Barat, Pontianak, 2011.

Kartajaya H. Winning The Mom Market in Indonesia (Strategi Membidik Pasar Ibu). PT. Gramedia Pustaka Utama, Jakarta, 2005.

Keputusan Menteri Kesehatan Republik

Indonesia Nomor: HK.03.01/I/2010.

Rencana Strategis Kementerian

Kesehatan Tahun 2010-2014. Kemenkes

RI, Jakarta, 2010.

Lestari D, Zuraida R, Larasati TA. Hubungan

Tingkat Pengetahuan Ibu tentang ASI dan

Pekerjaan Ibu dengan Pemberian ASI

Eksklusif di Kelurahan Fajar Bulan.

Medical Journal of Lampung. 2013;2:93

Mantra IB. Pretesting. Pusat Penyuluhan

Kesehatan Masyarakat Departemen

Kesehatan RI, Jakarta, 1997.

Mandesa EM, Sarimin DS, Ismanto AY.

Pengaruh Pendidikan Kesehatan

Terhadap Pengetahuan dan Sikap Orang

Tua tentang Kejadian Ikutan Paska

Imunisasi (KIPI). Ejournal Keperawatan (e-Kp) 2014; 2(1).

Marlina L, Saleh A, Lumintang RWE.

Perbandingan Efektivitas Media Cetak

(Folder dan Poster-Kalender) dan

Penyajian Tanaman Zodia terhadap

Peningkatan Pengetahuan Masyarakat.
Jurnal Komunikasi Pembangunan 2009; 07(2).

Muslikha P dan Purwanti S. Peran Leaflet ASI Eksklusif Terhadap Pengetahuan Ibu tentang ASI Eksklusif dan Motivasi untuk Menyusui secara Eksklusif di BPS Ny. Djuwedah Kebasen Kabupaten Banyumas. Bidan Prada : Jurnal Ilmiah Kebidanan 2011; 2(1).

Nasution N.A.H. Efektivitas Media Promosi Kesehatan (LEAFLET) Dalam Perubahan Pengetahuan Dan Sikap Ibu Hamil Tentang Inisiasi Menyusu Dini (IMD) Dan Asi Eksklusif Di Kecamatan Padangsidimpuan Selatan Kota Padangsidimpuan Tahun 2010 (Tesis). Universitas Sumatera Utara, Medan, 2010.

Notoatmodjo S. Promosi Kesehatan dan Ilmu Perilaku. Rineka Cipta, Jakarta, 2007.

Notoatmodjo S. Metodologi Penelitian Kesehatan. Rineka Cipta, Jakarta, 2012.

Riwidikdo H. Statistik Kesehatan. Nuha

Medika, Yogyakarta, 2012.

Rochalia LG. Efektivitas Media Folder Bagi Penyajian Pesan Tanaman Hias (Tesis). Sekolah Pascasarjana IPB, Bogor, 2005.

Shimp, Terrence A. Periklanan dan Promosi: Aspek Tambahan Komunikasi Pemasaran Terpadu. Erlangga, Jakarta, 2004. 
Jurnal Promosi Kesehatan Indonesia Vol. 12 / No. 1 / Januari 2017

Sugiyono. Metode Penelitian Kuantitatif

Kualitatif $R \& D$. Alfabeta, Bandung, 2007.

Sugiyono. Metode Peneitian Pendidikan

(Pendekatan kuantitatif, Kualitatif dan

R\&D). Afabeta, Bandung, 2013.

Supardi S, Sampurno OD, Notosiswoyo M.

Pengaruh Metode Ceramah dan Media

Leaflet Terhadap Perilaku Pengobatan

Sendiri yang Sesuai dengan Aturan.

Buletin Penelitian Kesehatan 2002;

30(3): 128-138.

Tanjung S, Tristanti I. Hubungan Tingkat

Pendidikan dengan Pengetahuan tentang

ASI Eksklusif pada Ibu Menyusui Bayi

(0-6) di RB Bunda Jaten Karanganyar. E-

Jurnal Maternal. 2011;5;40. 